\title{
CONTROL OF TGF-BETA RECEPTOR EXPRESSION IN BONE
}

\author{
Michael Centrella, Changhua Ji, Thomas L. McCarthy
}

Department of Surgery, Plastic Surgery Section, Yale University School of Medicine, 333 Cedar Street, PO Box 208041, New Haven, CT 06520-8041,

Received 12/1/97 Accepted 12/5/97

\section{TABLE OF CONTENTS}

1. Abstract

2. Introduction

3. Bone growth and remodeling

4. Bone growth regulators

5. TGF-beta supergene family and bone

6. TGF-beta receptors

7. Effects of TGF-beta on bone cell activity

8. Regulation of TGF-beta receptors on bone cells

9. TGF-beta receptor I promoter

10. Nuclear factor $\mathrm{CBFa}$

11. CBFa, TGF-beta receptor I, and bone

12. Perspective

13. Acknowledgment

14. References

\section{ABStract}

Bone growth and remodeling are controlled by local and systemic growth factors. The first local bone growth factor purified to homogeneity was transforming growth factor type beta (TGF-beta). On skeletal cells, TGF-beta has multiple effects mediated through at least three distinct cell surface receptors. More recent evidence demonstrated hormone and growth factor dependent alterations in TGF-beta receptor expression on osteoblasts in vitro. Indeed, certain biological responses appear to depend on the proportional expression of the type I TGF-beta receptor. Studies defining the type I TGF-beta receptor gene promoter then revealed that it contained several binding sequences for a nuclear factor that varies in parallel with expression of the osteoblast phenotype. New observations linking these events appear to enhance our understanding of this pivotal growth factor during osteogenesis and systemic bone disease.

\section{INTRODUCTION}

Transforming growth factor beta (TGF-beta) is a potent and ubiquitous growth regulator. It was first isolated from tumor extracts where it was thought to induce a "transformation" between normal and neoplastic cell growth. Since then, TGF-beta expression or its activity has been examined in essentially every tissue in the body. Surprisingly, its effects diverge considerably. Stimulatory, inhibitory, or negligible effects have been reported on the same biochemical processes, and even within cells from the same tissue lineage. Some variations relate to its release from inactive complexes, some to its concentration-dependent biphasic actions, and others to the differentiation status of target cells. Therefore, subtle control mechanisms must exist that regulate TGF-beta expression or its activity within tissues. All of these processes have also been noted in bone. Still, little is known about how the very same molecule produces such divergent effects, and especially, how these events change during tissue differentiation.

TGF-beta binding to cell surface components is altered by certain agents that activate or suppress bone cell activity. Moreover, systematic differences in the TGF-beta receptor profile can be observed between less and more differentiated bone cells, suggesting that differentiation-dependent molecular regulators must co-ordinate these transitions. In the last several years new molecular tools were developed to address these questions. As a result, work on TGF-beta receptor expression has converged with other studies demonstrating the importance of a specific nuclear factor that appears to drive osteogenesis. In this review, we describe the progression of results, obtained by us and other investigators, that revealed new insight into the control of TGF-beta receptor expression and TGFbeta activity in bone.

\section{BONE GROWTH AND REMODELING}

Bone is a dynamic tissue that forms and remodels throughout life. Bone formation increases during early life and declines during senescence. 
With many diseases or certain pharmacological interventions, osteoblast activity and bone formation decline. Bone loss then accelerates and its structural quality is reduced. This accompanies an increase in fracture and pain, and a decrease in mobility and function. Loss of bone integrity and much of its subsequent pathology may therefore follow an imbalance between osteoblastic bone formation and osteoclastic resorption that define the symmetrical sequence of normal bone remodeling (1-3).

\section{BONE GROWTH REGULATORS}

Bone cells are regulated by systemic (hormone) and local (bone-derived) factors (4-6). Hormonal effects are well appreciated, but local bone growth factors have only been identified and characterized in the last dozen years. By mass, bone is the largest reservoir of growth factors in the body (5-8). Many local bone growth factors are synthesized by osteoblasts. Also, bone matrix is a tenacious substrate, and some matrix-bound growth factors may originate from other tissues and produce important local actions after their release from remodeling bone. Initial efforts in this field described direct effects by local growth factors on bone cell activity. Other studies then centered on interactions that occur between systemic and local factors (9-19 among many others). Studies with fetal rat bone cultures first demonstrated TGF-beta in skeletal tissue. Cells derived from rat calvariae were then used to visualize TGF-beta receptors on bone cells (reviewed previously in reference 20). This culture model also provided the first evidence for detrimental effects by glucocorticoid on TGF-beta binding and function in any tissue, and new information for specific variations in TGF-beta receptors in parallel with expression of the osteoblast phenotype $(19,21)$. Results from these and other similar in vitro studies therefore began to predict that the effects of some bone growth regulators could converge with those induced by TGF-beta, perhaps in large part by changing the levels of specific TGFbeta receptors.

\section{TGF-BETA SUPERGENE FAMILY AND BONE}

Over 12 years ago, the growth factor isolated from rat bone culture medium, termed bone derived growth factor I, was identified as a homologue of TGF-beta type 1 (TGF-beta1) obtained from tumor extracts and blood platelets. Cartilage inducing factors from bovine bone were then recognized as TGF-beta isoforms, and it soon became clear that bone cells synthesize TGF-beta and that bone matrix is a major storage site for TGFbeta in the organism (20). The TGF-beta supergene family includes three isoforms of TGF-beta itself. Other less closely related gene family members are the bone morphogenetic proteins [BMPs]. The BMPs are stored in bone matrix and increase bone cell activity in vivo and in vitro, verifying a prominent role for TGF-betas and related molecules on bone formation (22-25). Many results now indicate independent roles for individual members of the TGF-beta supergene family and their receptors. The TGF-betas themselves are disulfide-linked dimers of 25 kilodaltons (kDa) $(26,27)$. They are synthesized and released from cells in inactive complexes containing amino-terminal cleavage products, and in many cases, latent TGF-beta binding protein [LTBP]. LTBP is not found in medium from mouse bone cultures and may not be necessary for latency, but it could direct secreted TGF-beta to matrix storage pools $(28,29)$. Latency might protect nascent TGFbeta from proteolysis and maintain a source of activatable TGF-beta. Activation of latent TGF-beta may be enzymatic. However, during bone resorption, TGF-beta might also be released from bone matrix and activated by the acidic micro-environment beneath the sealing zone of osteoclasts $(26,30)$.

\section{TGF- BETA RECEPTORS}

On osteoblasts, TGF-beta binds to high affinity receptors like those found on many other cells (11,31). Studies in chemically mutated mink lung epithelial cells implicated TGF-beta receptor I [TGF-betaRI of $53 \mathrm{kDa}$ ] and TGF-beta receptor II [TGF-betaRII of $75 \mathrm{kDa}$ ] in signal transduction (32). Different mutant mink lung cells were then isolated that express various levels of TGF-beta receptors. When intact or mutant TGF-beta receptors were transfected back into the mutated cells, TGF-beta appears first to bind TGF-betaRII. This complex can recruit TGF-betaRI, which itself also associates directly with TGF-beta. In this context, the kinase domain of TGF-betaRII phosphorylates TGFbetaRI, and downstream signals follow (33-36). Thus, TGF-betaRI is indispensable for TGF-beta activity. TGF-beta also binds with lower affinity to proteoglycans of $>250 \mathrm{kDa}$, first termed TGF-beta type III receptors [TGF-betaRIII], but now also called betaglycans (37-39). Cell surface betaglycans do not themselves initiate a biochemical event, but may facilitate extracellular storage of TGF-beta, control its activation, or regulate its binding to other TGF-beta receptors $(40,41)$. Consequently, the proportion rather than the actual amount of each of TGF-beta receptor may determine the extent of ligand binding in total, or it may focus TGF-beta to inactive, potentially active, or active receptors or receptor complexes (21). Receptors for several of the TGF-beta supergene family members appear similar to TGF-betaRI and/or TGF-betaRII. While interactions between TGF-betaRI, TGF-betaRII and receptors for other TGF-beta supergene family members have been reported in reconstituted cell models, homologous ligand/receptor binding appears to be specific in the normal situation (42-51). For example, bone cells express receptors for several 
TGF-beta supergene family members, but they preferentially bind TGF-beta at conventional TGFbetaRI, TGF-betaRII, and betaglycan $(11,21,23,45)$. Other less well characterized TGF-beta receptors $(20,31)$ have not been reported on osteoblasts. Again, many studies including those in bone predict changes in TGF-beta receptors during development, aging, or in response to specific hormones $(11,19,21,52-58)$.

The cDNAs for TGF-betaRI, TGF-betaRII, and betaglycan core protein, all prominently expressed by bone cells, are cloned $(33,36,46,59-$ $61)$, and specific antibodies are available to evaluate changes in TGF-beta protein. However, to understand how the expression of genes encoding the TGF-beta receptors are controlled during bone development, remodeling, and disease, promoter analysis is essential. Until recently only the TGFbetaRII promoter was cloned $(62,63)$. Because TGFbetaRI is maintained with bone cell differentiation (21) and is the essential component for all known TGF-beta dependent effects (31), our lab cloned the rat TGF-betaRI promoter (64) to assess cis- and trans-acting elements that regulate TGF-betaRI synthesis by bone cells. Aspects of these studies are described later in this review.

\section{EFFECTS OF TGF-BETA ON BONE CELL ACTIVITY}

In vivo, local administration of TGF-beta increases bone formation (65-67). However, the molecular mechanisms of TGF-beta activity in bone have principally been determined by studies with primary and continuous cultures of bone cells that express varying degrees of the osteoblast phenotype. TGF-beta modestly enhances replication of fibroblasts and undifferentiated periosteal cells, but it is a potent mitogen in osteoblast-enriched cultures from fetal rat bone. The stimulatory effect of TGFbeta on DNA synthesis decreases at high TGF-beta concentrations and in cell cultures derived from more mature organisms, and it inhibits replication by certain osteosarcoma derived cells that are thought to represent highly differentiated osteoblasts. The mitogenic effect of TGF-beta therefore appears to be focused on cells that are first prominent at an intermediate stage of bone development. In order to allow effective skeletal tissue formation, cell populations like these must need to re-emerge during bone remodeling or fracture repair $(20,21,68)$.

TGF-beta also alters the expression of many genes related directly to osteoblast activity. Consistent with its activity in many tissues, TGFbeta induces the synthesis of several matrix proteins by bone cells. Type I collagen comprises $90 \%$ of the organic matrix of bone and it is an essential element in skeletal calcification and structure. TGFbeta enhances type I collagen synthesis and the apposition of a collagen-containing matrix in cultures of isolated bone cells and in bone fragments (69-72). Studies in osteoblast-enriched cultures show that part of this effect is transcriptional, part is related to type I procollagen mRNA stability, and part derives from an increase in collagen secretion and its subsequent re-deposition to the cell layer (71). However, in cells prepared from human bone obtained after hip replacement surgery, TGF-beta only transiently increases type I procollagen mRNA and polypeptide levels, suggesting differences that could derive from disease state, age, or perhaps species variations (72). TGF-beta also induces the expression of other bone matrix components such as osteopontin and osteonectin. In contrast, it reduces the expression of a late stage osteoblast-derived protein, osteocalcin, in several osteoblast-like or osteosarcoma-derived cell cultures. Like the effect that occurs with most mitogenic factors, short term exposure to TGF-beta reduces the activity of alkaline phosphatase, a protein thought to be involved in matrix calcification, in fetal bone cells, but enhances its expression by some osteosarcoma and mature human bone cells $(20,72)$. Furthermore, TGF-beta rapidly re-organizes its own receptor profile on osteoblasts (73). Overall, the response patterns that occur in osteoblasts derived from fetal, neonatal, mature and osteoporotic bone, and from osteosarcomas predict distinct changes in sensitivity to TGF-beta at specific stages of osteoblast differentiation.

Variations in TGF-beta activity could perhaps in part be related to one or another isform of TGF-beta. Indeed, in osteoblast-enriched cell cultures, TGF-beta3 is $3-10$ fold more potent than TGF-beta1 or TGF-beta2. However, all three TGFbetas bind to the same three TGF-beta receptors, although with slightly different affinities, and in the end cause the same qualitative effects on osteoblast activity $(74,75)$. Therefore, unlike the patterns that are found with endothelial cell cultures (41), dissimilarities in TGF-beta activity on bone cells do not seem to result from differences in the association of certain TGF-beta isoforms with only specific combinations of TGF-beta receptors.

\section{REGULATION OF TGF-BETA RECEPTORS ON BONE CELLS}

Variations in TGF-beta receptor levels appear to parallel the changes in TGF-beta activity that occur as bone cell differentiation proceeds. Notably, the relative amounts of betaglycan, measured by both radio-iodinated TGF-beta binding assay and by mRNA analysis, are significantly lower on differentiated osteoblasts $(11,21,68)$; this predicts that betaglycan expression is reduced as osteoblasts mature. The proportions of TGF-betaRI and TGFbetaRII also vary, and do so independently from each other, during this process. Specifically, in fetal 
rat bone cells, the relative amount of TGF-beta binding to TGF-betaRII also decreases when osteoblast-like activity increases and betaglycan levels fall, while the proportion of TGF-beta binding to TGF-betaRI increases significantly. These patterns too are consistent with changes in steady state mRNA levels for TGF-betaRI and TGF-betaRII (21).

Some studies in the pre-osteoblastic neonatal murine MC3T3-E1 cell line suggest large decreases in all three $\mathrm{TGF}$-beta receptors and in TGF-beta function during the processes of collagen matrix deposition and mineralization $(76,77)$ in vitro. Changes like this do not appear to occur in primary osteoblast-enriched cell cultures from fetal rat bone (45, and other unpublished studies). These differences may relate to the phenotype of MC3T3E1 cells that endogenously express very little TGFbetaRI (68). Thus, in the absence of specific osteogenic inducers, changes in the proportion of TGF-betaRI may be difficult to note when its levels are initially so low. In contrast, and perhaps more consistent with results in primary bone cell cultures, immunohistochemical staining during mouse organogenesis showed a more ubiquitous staining pattern for TGF-betaRI than for TGF-betaRII. In these studies, staining for TGF-betaRII was preferentially found in regions of undifferentiated cells that thereafter differentiated into bone (78), much like the changes that occur in fetal rat cell cultures (21). Furthermore, in human osteosarcoma derived MG-63 cell cultures, differentiation induced by 1,25 dihydroxyvitamin D3, suppresses the levels of TGF-betaRII in parallel with a decrease in certain aspects of TGF-beta activity (79).

Agents that increase TGF-beta binding to betaglycan tend to reduce the stimulatory effects of TGF-beta on osteoblast function. Small but significant increases in binding occur in response to parathyroid hormone, and larger and more sustained effects occur with glucocorticoid treatment $(11,19,80)$. However, although betaglycan levels can vary dramatically on bone cells with differentiation (described above), with these osteotropic hormones, or with growth factor treatment (see below), lack of promoter information has severely limited our ability to understand how these events occur at the molecular level. Glucocorticoid decreases TGF-beta binding to a small extent to TGF-betaRII, an effect that increases with longer exposure to hormone (19). Nonetheless, initial studies with TGF-betaRII promoter constructs (63) show no consistent changes in promoter activity when bone cells are treated with glucocorticoid, or with BMP-2, TGFbeta, PGE2, or retinoic acid (unpublished data). These results and earlier studies showing large changes in betaglycan in response to these agents $(19,21,73$, and unpublished data) support that TGFbeta binding to TGF-betaRII is in part regulated indirectly by the proportion of betaglycan present on the cell surface $(21,41,81)$. Little else is currently known about the molecular mechanisms that mediate changes in betaglycan or TGF-betaRII expression in bone cells or in any tissue.

In contrast to small or negligible changes in TGF-betaRII, the proportion TGF-beta binding to TGF-betaRI is rapidly and significantly affected by positive and negative regulators of osteoblast activity $(19,21)$. New studies, described in more detail below, predict how changes in TGF-betaRI expression may occur by variations in the level of a more recently appreciated, osteoblast-restricted nuclear factor, CBFa1.

As described earlier, other TGF-beta supergene family members that regulate skeletal cells include the BMPs. These agents were first defined by a functional assay where they initiated cartilage formation that was then replaced by bone at ectopic sites in vivo in the rat $(20,22)$. Some BMPs are more effective on osteoblasts, and others are more effective on less differentiated bone cells. Certain effects induced by several BMP family members are distinct from those induced by TGF-betas, and in some instances differ even from each other. BMPs enhance the synthesis of cartilage proteoglycan, alkaline phosphatase, osteocalcin, and PTH receptors in cultures of uncommitted stromal cells, chondrocytes, and/or osteoblast-like cells $(21,45,81$ 92). Mutations in the mouse short ear gene (that is genetically related to human BMP-5) correlate with abnormal growth, skeletal formation, and fracture repair in these animals (93). BMPs act through specific BMP receptors and do not directly compete for binding at high affinity TGF-beta receptors. Nevertheless, BMP-2 and BMP-4 potently alter TGFbeta binding on osteoblasts. In direct contrast to the effects of glucocorticoid, these BMPs rapidly decrease TGF-beta binding to TGF-betaRII and betaglycan, and increase its binding to TGF-betaRI. In so doing, BMP treatment alters the effects of TGF-beta on bone cell replication, matrix protein synthesis, and alkaline phosphatase activity in patterns that are consistent with progressive increases in osteoblast differentiation (21). Other studies recently showed that BMP-2 can oppose the inhibitory effect of glucocorticoid on TGF-beta binding and activity. Surprisingly, BMP-2 also suppresses the stimulatory effect of glucocorticoid on a gene promoter containing a positive glucocorticoid response element (94).

Some osteoblast regulators may therefore alter TGF-beta induced osteoblast activity by redistributing TGF-beta binding among its various receptors. Changes in TGF-beta binding may in part depend on new TGF-beta receptor synthesis $(19,20,73)$. While these findings suggest that effects by several regulators of bone cell activity converge at 
the molecular level on TGF-beta receptor expression, detailed information requires the new molecular tools that have become available only recently.

\section{TGF-BETA RECEPTOR I PROMOTER}

Consequently, variations in TGF-beta receptors can define the extent or the nature of TGF-beta activity for bone cells. Initial studies to understand how this occurs suggested a very short half-life of 2-6 $\mathrm{h}$ for cell surface TGF-beta receptor proteins in untreated bone cell cultures. In some instances, there is a rapid recovery after hormone or growth factor treatments. Measurements of transcript half-lives of 6-20 h for TGF-beta receptor mRNAs show reasonable turnover rates, and predict that constitutive expression is needed to maintain an adequate supply of cell surface TGF-beta receptor protein (73). Again, TGF-betaRI is essential for TGF-beta activity. Its mRNA half-life is short (6-7 h) by comparison to TGF-betaRII and betaglycan (17$20 \mathrm{~h}$ ), and its expression varies in appropriate ways on bone cells with differentiation and in response to specific bone growth regulators. To examine transcriptional control of TGF-betaRI in better detail, its promoter was cloned in our lab from a rat genomic library (64). Consistent with the widespread importance of TGF-beta in most tissues, the organization of the TGF-betaRI promoter is like many constitutively expressed genes. The rat TGF-betaRI promoter is very similar to the human TGF-betaRI promoter that was cloned by others simultaneously (95). However, reporter constructs used to analyze the human TGF-betaRI promoter failed to include important upstream and downstream control elements that our lab established by sequence, reporter, gel shift, and mutation analyses. Deletions and point mutations showed that two downstream CCAAT boxes in the TGF-betaRI promoter do not contribute to its expression in osteoblasts. In contrast, the promoter contains multiple binding sequences for transcription factor $\mathrm{Sp} 1$, a condition that is often associated with constitutive gene expression $(96,97)$. The many Sp1 binding sequences may contribute in part to multiple transcription start sites (64). Also, at least one Sp1 site is essential for basal TGF-betaRI promoter activity (96). Even so, and consistent with initial observations of TGF-betaRI mRNA and protein (21), the TGF-betaRI promoter is significantly more active in more differentiated bone cells (64). This predicted the presence of tissue specific cisacting elements within the TGF-betaRI promoter itself, and specific trans-acting factors within osteoblast nuclei $(96,98)$. Consistent with this possibility, there are four separate binding sequences for members of the $\mathrm{CBFa}$ transcription factor family within the maximally active $1.0 \mathrm{~kb}$ region of the TGF-betaRI promoter, and two others within the next 5' 0.1 $\mathrm{kb}$ (98).

\section{NUCLEAR FACTOR CBFa}

The $\mathrm{CBFa}$ transcription factors were independently identified by several labs and termed CBFs, PEBP2 alphas, AMLs, or NMPs. Due to confusion with names of diseases or other transcription factor families, it has been suggested that the two subunits for these factors should be termed as $\mathrm{CBFa}$ and $\mathrm{CBFb}$. Thus, active nuclear factor contains one $\mathrm{CBFa}$ subunit $(\mathrm{CBFa} 1, \mathrm{CBFa} 2$ or $\mathrm{CBFa} 3$ ), and a common $\mathrm{CBFb}$ subunit that greatly increases CBFa subunit binding to DNA (99-102). CBFa subunits contain a so-called Runt homology domain, derived from its similarity to a transcription factor involved in cell fate associated with body segmentation, sex determination, and neurogenesis in Drosophila. The $\mathrm{CBFa}$ Runt domain contains binding sites for DNA and for the CBFb subunit. The $\mathrm{COOH}$-terminal region of the $\mathrm{CBFa}$ subunit contains a transactivation domain required for $\mathrm{CBFa}$ dependent gene transcription. $\mathrm{CBFa} 1$ and $\mathrm{CBFa} 2$ also contain sites that can be phosphorylated by components of the mitogen activated protein (MAP) kinase system that are activated in response to certain growth factors and cytokines, and perhaps phorbol esters. Phosphorylation may have a potent stimulatory effect on $\mathrm{CBFa}$ dependent gene transcription $(103,104)$. CBFb subunits tend to be ubiquitous and over expressed, and uncomplexed $\mathrm{CBFb}$ subunits accumulate in the cytoplasm (99). Gene expression regulated by $\mathrm{CBFa}$ can therefore result from: 1) variations in three different $\mathrm{CBFa}$ subunits that themselves may distinguish several cis-acting DNA binding sequences in subtle ways; 2 ) by the amount or the intracellular location of the common $\mathrm{CBFb}$ subunit; 3) or by growth regulators that activate or suppress osteogenic cell function.

In addition, other proteins can associate with the $\mathrm{CBFa}$ or $\mathrm{CBFb}$ subunits independently. For example, transcription factors termed C/EBPs physically interact with $\mathrm{CBFa} 2$ through the Runt domain common to all $\mathrm{CBFa}$ subunits, and synergistically enhance M-CSF receptor (c$\mathrm{fms}$ ) gene expression in macrophage-like cells (105). Other interactions have also been noted with nuclear factors cMyb and with Ets family members in the neutrophil elastase and myeloperoxidase promoters $(106,107)$. Functional levels of C/EBP beta and C/EBP delta are found in osteoblasts (108) predicting that similar interactions may occur in bone cells. $\mathrm{CBFb}$ subunits have wider tissue distribution than $\mathrm{CBFa}$ subunits. This and the existence of a large $\mathrm{CBFb}$ cytoplasmic pool, suggests that other binding partners exist, or modifications are needed to promote nuclear localization or association with $\mathrm{CBFa}$ subunits, but how this occurs is not yet clear (100, and personal communications from Dr. Yoshiaki Ito, Kyoto University, Japan; and Dr. J. Peter Gergen, State University of New York at Stonybrook).

\section{CBFa, TGF-BETA RECEPTOR I, AND BONE}

The function of $\mathrm{CBFa}$ as a nuclear regulator initially seemed restricted to the expression of genes important to blood cell differentiation in higher organisms. Compatible with this, some leukemias correlate well with translocations in the $\mathrm{CBFa}$ or $\mathrm{CBFb}$ subunit genes. In two cases, breaks occur in the $\mathrm{COOH}$-terminal transactivation region of the $\mathrm{CBFa}$ subunit. This perhaps allows strong binding by the intact Runt domain to the $\mathrm{CBFb}$ subunit and to DNA, even while it prevents effective transactivation at target gene promoter sites. Another translocation occurs at a site upstream of the Runt domain, and another within the $\mathrm{CBFb}$ subunit. While each effectively alters target gene 
expression in lymphoid cells, the molecular details of these events are not yet resolved $(109,110)$. For example, new studies from Dr. Ito's lab reveal that a splice variant of $\mathrm{CBFa} 2$, lacking a portion of the Runt domain, inhibits $\mathrm{CBFa}$ dependent $\mathrm{T}$ cell receptor promoter activity, myeloid cell proliferation and differentiation independently of its ability to bind DNA (111). Consistent with the widespread effects of CBFa-like transcription factors in Drosophila, other recent studies reveal the presence of these factors in muscle (112).

Work from Drs. Jane Lian and Gary Stein (University of Massachusetts Medical Center, Worcester), and Dr. Gerard Karsenty (MD Anderson Cancer Center, Houston) further reveal that $\mathrm{CBFa}$ may be an important regulator of osteocalcin expression by osteoblasts (113118). One $\mathrm{CBFa}$ binding site may contribute as much as $75 \%$ to the activity of the osteocalcin promoter in osteoblast-like cells, perhaps accounting in part for the tissue-specific expression of this protein (116). Most importantly, after the osteocalcin studies and work from our lab with the TGF-betaRI promoter were reported (1996 meeting of the American Society for Bone and Mineral Research, abstract \#56), Dr. Toshihisa Komori (Osaka University, Japan) produced mice in which the gene for the CBFa1 subunit was "knocked-out". Animals died very soon after birth and suffered severe osteogenic deformities, while cartilage formation appeared intact (119). Analogous results were seen by Dr. Michael J. Owen's group (IRCF, London) (120). Mineralized skeletal elements consistent with osteoblast-dependent bone formation were not evident in these animals, and few if any cells with osteoblast morphology were apparent. Consistent with insertion, deletion or missense mutations in $\mathrm{CBFa}$ that occur in humans, these mice are considered models for the skeletal disorder cleidocranial dysplasia (119-121). However, genes directly effected by CBFa1, especially those important for skeletal development, are difficult to determine when the factor is absent or dysfunctional, and when osteoblasts are absent or hard to detect. Hormone dependent decreases in $\mathrm{CBFa} 1$ could also challenge skeletal integrity and more readily indicate important downstream targets. In this regard, our lab noted changes in CBFa1 expression with osteoblast differentiation (98), and that glucocorticoid rapidly and potently suppressed $\mathrm{CBFa} 1$ levels, $\mathrm{CBFa} 1$ binding to the TGF-betaRI promoter, TGF-betaRI promoter activity, TGF-betaRI mRNA and protein levels, and TGF-beta function in primary osteoblast cultures (122). We also find increases in CBFal expression by osteoblasts in response to BMP-2 (unpublished studies). These studies establish new molecular links in osteoblasts to CBFa1 with regard to important extracellular bone cell regulators and to a new genomic target, TGF-betaRI. These findings, changes in the expression of TGF-betaRI during osteoblast differentiation, and the importance of TGF-beta and TGF-betaRI for osteoblast activity suggest that our unique new observations with the TGF-betaRI promoter will significantly influence our understanding of TGF-beta biological activity in skeletal tissue, and of CBFa1-dependent control of bone cell function.

\section{PERSPECTIVE}

TGF-beta is abundant in bone and is a potent regulator of osteoblast activity. The TGF-beta receptor profile varies with the state of osteoblast differentiation. Notably, the proportion of TGFbetaRI fluctuates in response to important systemic and local agents, consistent with changes in osteoblast function. To understand this in molecular detail, the TGF-betaRI promoter was cloned, and found to contain several binding sequences for tissue-restricted transcription factors termed CBFa. Several labs have now shown enrichment for one CBFa subunit, CBFa1, with osteoblast differentiation. Loss of CBFa1 by gene elimination limits skeletal tissue formation essentially to chondrogenesis. Furthermore, initial evidence indicates specific variations in $\mathrm{CBFa} 1$ in response to positive and negative regulators of the osteoblast phenotype. Studies in nonskeletal cells predict important interactions between $\mathrm{CBFa}$ and other nuclear proteins, and regulation of CBFa activity by transcriptional and post-transcriptional events. Our observations revealing molecular links between CBFal and TGF-betaRI provide further evidence that TGF-beta is an important factor in osteogenesis. Changes in TGF-betaRI expression provide a tight and phenotype dependent gatekeeper system that controls how the effects of TGF-beta are perceived. New information to understand the normal mechanisms that control TGF-betaRI through CBFa1 expression and activity in bone cells will improve our understanding of its important role in skeletal tissue growth, remodeling and repair.

\section{ACKNOWLEDGMENT}

The authors were supported by NIH awards AR39201 and DK47421 during the preparation of this manuscript.

\section{REFERENCES}

1. Rodan, G. A. \& T. J. Martin: Role of osteoblasts in hormonal control of bone resorption-a hypothesis. Calc. Tiss. Int. 33, 349-351 (1981)

2. Martin, T.J., K.W. Ng, \& T. Suda: Bone cell physiology. Endocr. and Metab. Clin. North Am. 18, 833-858 (1989)

3. Teitelbaum, S.L.: Molecular defects of bone development. In: Primer on the metabolic bone diseases and disorders of mineral metabolism. Ed. Fauvus, M.J. , Raven Press, NY. 2nd edition, 10-15 (1993)

4. Raisz, L.G.: Local and systemic factors in the pathogenesis of osteoporosis. N. Engl. J. Med. 318, 818828 (1988)

5. Centrella, M., T.L. McCarthy, E. Canalis: Growth factors and cytokines. In: Bone: Bone metabolism 
and mineralization. Ed. B.K. Hall, editor, CRC Press Inc., Boca Raton, FL, volume 4, 47-72 (1992)

6. Mundy, G.R. (1993) Bone resorbing cells. In: Primer on the metabolic bone diseases and disorders of mineral metabolism. Ed. Fauvus, M.J. , Raven Press, NY. 2nd edition, 25-32 (1993)

7. Hauschka, P.V., A.E. Mavrakos, M.D. Iafrati, S.E. Doleman, \& M. Klagsbrun: Growth factors in bone matrix: isolation of multiple types by affinity chromatography on heparin sepharose. J. Biol. Chem. 261, 12665-12674 (1986)

8. Linkhart, T.A., J.C. Jennings, S. Mohan, G.K. Wakley \& D.J. Baylink: Characterization of mitogenic activities extracted from bovine bone matrix. Bone 7 , 479-487 (1986)

9. Pfeilschifter, J. \& G.R. Mundy: Modulation of type beta transforming growth factor activity in bone cultures by osteotropic hormones. Proc. Natl. Acad. Sci. USA 84, 2024-2028 (1987)

10. Petkovich, P.M., J.L. Wrana, A.E. Grigoriadis, J.N.M. Heersche \& J. Sodek: 1,25 dihydroxyvitamin D3 increases epidermal growth factor receptors and transforming growth factor beta-like activity in a bone-derived cell line. J. Biol. Chem. 262, 1342413428 (1987)

11. Centrella, M., T.L. McCarthy \& E. Canalis: Parathyroid hormone modulates transforming growth factor beta activity and binding in osteoblastic cells. Proc. Natl. Acad. Sci. USA 85, 5889-5893 (1988)

12. Komm, B.S., C.M. Terpening, D.J. Benz, K.A. Graeme, A. Gallegos, M. Korc, G.L. Greene , B.W. O'Malley \& M.R. Haussler: M.R. Estrogen binding receptor mRNA and biologic response in osteoblastlike osteosarcoma cells. Science 241, 81-84 (1988)

13. McCarthy, T.L., M. Centrella, \& E. Canalis: Parathyroid hormone enhances the transcript and polypeptide levels of insulin-like growth factor I in osteoblast-enriched cultures from fetal rat bone. Endocrinology 124, 1247-1253 (1989)

14. Centrella, M., T.L. McCarthy \& E. Canalis: beta2-Microglobulin (beta2m) enhances insulin-like growth factor I binding and synthesis in bone cell cultures. J. Biol. Chem. 264, 18268-18271 (1989)

15. McCarthy, T.L., M. Centrella \& E. Canalis: Cortisol inhibits the synthesis of insulin-like growth factor I in bone cell cultures. Endocrinology 126, 1569-1575 (1990)

16. Marusic, A., J.F. Kalinowski, J.R. Harrison, M. Centrella, L.G. Raisz \& J.A. Lorenzo: Effects of transforming growth factor beta and interleukin 1 on prostaglandin synthesis in serum-deprived osteoblastic cells. J. Immunol. 146, 2633-2638 (1991)

17. McCarthy, T.L., E. Canalis \& M. Centrella: Cortisol differentially modulates insulin-like growth factor I and II binding on osteoblast-enriched fetal rat bone cells. J. Bone Miner. Res. 5, abstract S138 (1990)

18. Chen, T.L., L.Y. Chang, R.L. Bates \& A. Perlman: Dexamethasone and 1,25-dihydroxyvitamin D3 modulation of insulin-like growth factor binding proteins in rat osteoblast-like cell cultures. Endocrinology 128, 73-80 (1991)

19. Centrella, M., T.L. McCarthy \& E. Canalis: Glucocorticoid regulation of transforming growth factor beta1 (TGF-beta1) activity and binding in osteoblast-enriched cultures from fetal rat bone. Mol. Cell. Biol. 11, 4490-4496 (1991)

20. Centrella, M., V. Rosen, M.C. Horowitz, J.M. Wozney \& T.L. McCarthy: Transforming growth factor-b gene family members, their receptors, and bone cell function. In: Hormonal regulation of bone mineral metabolism. Eds. Bikle, D.D. , Nego-Vilar, A., Endocrine Society Press, Bethesda MD. 211-226 (1995)

21. Centrella, M., J. Kim, T. Pham, S. Casinghino, V. Rosen, J. Wozney \& T.L. McCarthy: Independent changes in type I and type II receptors for transforming growth factor beta induced by bone morphogenetic protein-2 parallel expression of the osteoblast phenotype. Mol. Cell. Biol. 15, 3273-3281 (1995)

22. Celeste, A.J., J.A. Ianazzi, R.C. Taylor, R.M. Hewick, V. Rosen, E.A. Wang \& J.M. Wozney: Identification of transforming growth factor beta family members present in bone-inductive protein purified from bovine bone. Proc. Natl. Acad. Sci. USA 87, 9843-9847 (1990)

23. Centrella, M., T.L. McCarthy \& E. Canalis: Activin-A binding and biochemical effects in osteoblast-enriched cultures from fetal rat parietal bone. Mol. Cell. Biol. 11, 250-258 (1991)

24. Ogawa, Y., D.K. Schmidt, R.M. Nathan, R.M. Armstrong, K.L. Miller, S.J. Sawamura, J.M. Ziman, K.L. Erickson, E.R. deLeon, D.M. Rosen, S.M. Seyedin, C.B. Glaser, Chang, R.-J. Chang, A.Z. Corrigan \& W.W. Vale: Bovine bone activin enhances bone morphogenetic protein-induced ectopic bone formation. J. Biol. Chem. 267, 1423314237 (1992)

25. Roberts, V.J. , P.E. Sawchenko \& W. Vale: Expression of inhibin/activin subunit messenger 
ribonucleic acids during rat embryogenesis. Endocrinology 128, 3122-3129 (1991)

26. Roberts A.B., \& M.B. Sporn: Transforming growth factor betas. In : Peptide growth factors and their receptors,. Eds. Sporn, M.B., Roberts, A.B.. Springer-Verlag, Heidelberg, Germany. 419-472 (1990)

27. Ogawa, Y., D.K. Schmidt, J.R. Dasch, R.-J. Chang \& C.B. Glaser: Purification and characterization of transforming growth factorbeta2.3 and 1.2 heterodimers from bovine bone. $J$. Biol. Chem. 267, 2325-2328 (1992)

28. Bonewald, L.F., L. Wakefield, R.O.C. Oreffo, A. Escobedo, D.R. Twardzik \& G.R. Mundy: Latent forms of transforming growth factor-beta (TGFbeta) derived from bone cultures: identification of a naturally occurring $100 \mathrm{kDa}$ complex with similarity to recombinant latent TGFbeta. Molec. Endocrinol. 6, 741-751 (1991)

29. Gibson, M.A., G. Hatzinikolas, E.C. Davis, E. Baker, E., G.R. Sutherland \& R.P. Mecham: Bovine latent transforming growth factor beta1-binding protein 2: molecular cloning, identification of tissue isoforms, and immunolocalization to elastinassociated microfibrils. Mol. Cell. Biol. 15, 69326942 (1995)

30. Baron, R., L. Neff, I. Louvard \& P.J. Courtoy: Cell-mediated extracellular acidification and bone resorption: evidence for a low $\mathrm{pH}$ in resorbing lacunae and localization of a 100-kd lysosomal membrane protein at the osteoclast ruffled border. $J$. Cell Biol. 101, 2210-2222 (1985)

31. Massague, J., L. Attisano \& J.L. Wrana: The TGF-beta family and its composite receptors. Trends. Cell. Biol. 4, 72-178 (1994)

32. Laiho, M., F.M.B. Weis \& J. Massague: Concomitant loss of transforming growth factor (TGF)-beta receptor types I and II in TGF-beta-resistant cell mutants implicates both receptor types in signal transduction. J. Biol. Chem. 265, 18518-18524 (1990)

33. Lin, H.Y., X.-F. Wang, E. Ng-Eaton, R.A. Weinberg \& H.F. Lodish: Expression cloning of the TGF-beta type II receptor, a functional transmembrane serine/threonine kinase. Cell 68, 775-785 (1992)

34. Ohtsuki, M. \& J. Massague: Evidence for the involvement of protein kinase activity in transforming growth factor-beta signal transduction. Mol. Cell. Biol. 12, 261-265 (1992)

35. Wrana, J.L., L. Attisano, R. Wieser, F. Ventura \& J. Massague: Mechanism of activation of the TGFbeta receptor. Nature (London) 370, 341-347 (1994)
36. Ebner, R., H.-W. Chen, L. Shum, S. Lawler, T.F. Zioncheck, A. Lee, A.R. Lopez \& R. DeRynck: Cloning of a type I TGF-beta receptor and its effect on TGF-beta binding to the type II receptor. Science 260, 1344-1348 (1993)

37. Segarini, P.R. \& S.M. Seyedin: The high molecular weight receptor to transforming growth factor -beta contains glycosamino glycan chains. J. Biol. Chem. 263, 8366-8370 (1988)

38. Andres, J.L., K. Stanley, S. Cheifetz \& J. Massague: Membrane-anchored and soluble forms of betaglycan, a polymorphic proteoglycan that binds transforming growth factor-beta. J. Cell Biol. 109, 3137-3145 (1989)

39. Cheifetz, S., J.L. Andres and J. Massague: The transforming growth factor-beta receptor type III is a membrane proteoglycan; domain structure of the receptor. J. Biol. Chem. 263, 16984-16991 (1988)

40. Lopez-Casillas, F., H.M. Payne, J.L. Andres \& J. Massague: Betaglycan can act as a dual modulator of TGF-beta access to signaling receptors: mapping of ligand binding and GAG attachment sites. J. Cell Biol. 124, 557-568 (1994)

41. Sankar, S., N. Mahooti-Brooks, M. Centrella, T.L. McCarthy \& J.A. Madri: Expression of transforming growth factor beta type III receptor in bovine endothelial cells increases their responsiveness to transforming growth factor beta2. J. Biol. Chem. 270, 13567-13572 (1995)

42. Cheifetz, S., N. Ling, R. Guillemin \& J. Massague: A surface component on GH3 pituitary cells that recognizes transforming growth factor-beta, activin, and inhibin. J. Biol. Chem. 263, 17225-17228 (1988)

43. Mathews, L.S. \& W.W. Vale: Characterization of type II activin receptors: binding, processing and phosphorylation. J. Biol. Chem. 268, 19013-19018 (1993)

44. Attisano, L., J. Carcamo, F. Ventura, F.M.B. Weis, J. Massague, \& J.L. Wrana: Identification of human activin and TGF beta type I receptors that form heteromeric kinase complexes with type II receptors. Cell 75, 671-680 (1993)

45. Centrella, M., S. Casinghino, C. Gundberg, T.L. McCarthy, J. Wozney \& V. Rosen: Changes in bone morphogenetic protein (BMP) sensitivity relative to differentiation in fetal rat bone cell cultures. Ann. NY Acad. Sci. 785, 224-226 (1996)

46. Franzen, P. , P. tenDijke, H. Ichijo, H. Yamashita, P. Schulz, C.-H. Heldin \& K. Miyazono: Cloning of a TGFbeta type I receptor that forms a 
heteromeric complex with the TGFbeta type II receptor. Cell 68, 681-692 (1993)

47. Estevez, M., L. Attisano, J.L. Wrana, P.S. Albert, J. Massague \& D.L. Riddle: The $d a f-4$ gene encodes a bone morphogenetic protein receptor controlling $C$. elegans dauer larva development. Nature(London) 365, 644-649 (1993)

48. Nellen, D., M. Affolter \& K. Basler: Receptor serine/threonine kinases implicated in the control of Drosophila body pattern by decapentaplegic. Cell 78, 225-237 (1994)

49. Penton, A., Y. Chen, K. Staehling-Hampton, J.L. Wrana, L. Attisano, L., J. Szidonya, J.A. Cassill, J. Massague \& F.M. Hoffman: Identification of two bone morphogenetic protein type I receptors in Drosophila and evidence that Brk25D is a decapentaplegic receptor. Cell 78, 239-250 (1994)

50. Brummel, T.J., V. Twombly, G. Marques, J.L. Wrana, S.J. Newfeld, L. Attisano, J. Massague, M.B. O'Connor \& W.M. Gelbart: Characterization and relationship of dpp receptors encoded by the saxophone and thick vein genes in Drosophila. Cell 78, 251-261 (1994)

51. tenDijke, P., H. Yamashita, T.K. Sampath, A.H. Reddi, M. Estevez, M., D.L. Riddle, H. Ichijo, C.-H. Heldin \& K. Miyazono: Identification of type I receptors for osteogenic protein-1 and bone morphogenetic protein-4. J. Biol. Chem. 269, 1698516988 (1994)

52. Rizzino, A.: Appearance of high affinity receptors for type beta transforming growth factor during differentiation of murine embryonal carcinoma cells. Cancer Research 47, 4386-4390 (1987)

53. Ewton, D.Z., G. Spizz, E.N. Olson \& J.R. Florini: Decrease in transforming growth factor-beta binding and action during

differentiation in muscle cells. J. Biol. Chem. 263, 4029-4032 (1988)

54. Kypriaou, N. \& J. Isaacs: Identification of a cellular receptor for transforming growth factor-beta in rat ventral prostate and its negative regulation by androgens. Endocrinology 123, 2124-2131 (1988)

55. Cochet, C., J.J. Feige, J.J. \& E.M. Chambaz: Bovine adrenocortical cells exhibit high affinity transforming growth factor-beta receptors which are regulated by adrenocorticotropin. J. Biol. Chem. 263, 5707-5713 (1988)

56. Gazit, D., R. Ebner, A.J. Kahn \& R. Derynck: Modulation of expression and cell surface binding of members of the transforming growth factor-beta superfamily during retinoic acid-induced osteoblastic differentiation of multipotential mesenchymal cells. Mol. Endocrinol. 7, 189-198 (1993)

57. Hu, J.-S. \& E.N. Olson: Functional receptors for transforming growth factor-betae retained by biochemically differentiated C2 myocytes in growth factor deficient medium containing EGTA, but downregulated during terminal differentiation. J. Biol. Chem. 265, 7914-7919 (1990)

58. Centrella, M., E. Canalis, T.L. McCarthy, J.J. Orloff, A.F. Stewart \& K.L. Insogna: Parathyroid hormone-related protein modulates the effects of transforming growth factor beta on deoxyribonucleic acid and collagen synthesis in fetal rat bone cells. Endocrinology 125, 199-208 (1989)

59. Lopez-Casillas, F., S. Cheifetz, J. Doody, J.L. Andres, W.S. Lane \& J. Massague: Structure and expression of the membrane proteoglycan betaglycan, a component of the TGF-beta receptor system. Cell 67, 785-795 (1991)

60. Wang, X.-F., H.Y. Lin, E. Ng-Eaton, J. Downward, H.F. Lodish \& R.A. Weinberg: Expression cloning and characterization of the TGFbeta type III receptor. Cell 67, 797-805 (1991)

61. Bassing, C.H., J.M. Yingling, D.J. Howe, T. Wang, W.W. He, M.L. Gustafson, P. Shah, P.K. Donahoe \& X.-F. Wang: A transforming growth factor beta type I receptor that signals to activate gene expression. Science 263, 87-89 (1994)

62. Humphries, D.E., B.B. Bloom, A. Fine \& R.H. Goldstein: Structure and expression of the promoter for the human type II transforming growth factorbeta receptor. Biochem. Biophys. Res. Commun. 203, 1020-1027 (1994)

63. Bae, H.W., A.G. Geiser, D.H. Kim, M.T. Chung, J.K. Burmester, M.B. Sporn, A.B. Roberts \& S.-J. Kim: Characterization of the promoter region of the human transforming growth factor-beta type II receptor gene. J. Biol. Chem. 270, 29460-29468 (1995)

64. Ji, C., S. Casinghino, T.L. McCarthy \& M. Centrella: Cloning, characterization and expression of a rat transforming growth factor-beta type I receptor promoter. J. Cell. Biochem. 63:478-492 (1996)

65. Noda, M. \& J.J. Camilliere: In vivo stimulation of bone formation by transforming growth factor-beta. Endocrinology 124, 2991-2994 (1989)

66. Marcelli, C., A.J. Yates \& G.R. Mundy: In vivo effects of human recombinant transforming growth factor beta on bone turnover in normal mice. J. Bone Mineral Res. 5, 1087-1096 (1990) 
67. Beck, L.S., A.J. Ammann, A.J., T.B. Aufdemorte, L. Deguzman, Y. Xu, W.P. Lee, L.A. McFatridge \& T.L. Chen: In vivo induction of bone by recombinant human transforming growth factor beta1. J. Bone Mineral Res. 6, 961-968 (1991)

68. Centrella, M.: Growth factor receptors and responses: Comparison between normal and osteosarcoma-derived cell cultures. In: Frontiers in osteosarcoma research. Eds. Novak, J.F., McMaster, J.H.. Hogrefe and Huber, Inc., Toronto, Canada. 457-468 (1993)

69. Centrella, M., T.L. McCarthy \& E. Canalis: Transforming growth factor beta is a bifunctional regulator of replication and collagen synthesis in osteoblast-enriched cell cultures from fetal rat calvariae. J. Biol. Chem. 262, 2869-2874 (1987)

70. Hock, J., E. Canalis \& M. Centrella: Transforming growth factor beta (TGFbeta-1) stimulates bone matrix apposition and bone cell replication in cultured fetal rat calvariae. Endocrinology 126, 421-426 (1990)

71. Centrella, M., S. Casinghino, R. Ignotz \& T.L. McCarthy: Multiple regulatory effects by transforming growth factor type b (TGF-beta1) on type I collagen levels in osteoblast-enriched cultures from fetal rat bone. Endocrinology 131, 2863-2872 (1992)

72. Strong, D.D., A.L. Beachler, J.E. Wergedal \& T.A. Linkhart: Insulinlike growth factor II and transforming growth factor beta regulate collagen expression in human osteoblastlike cells in vitro. $J$. Bone Miner. Res. 6, 15-23 (1991)

73. Centrella, M., C. Ji, S. Casinghino \& T.L. McCarthy: Rapid flux in transforming growth factor beta receptors on bone cells. J. Biol. Chem. 271, 18616-18622 (1996)

74. tenDijke, P., K.K. Iwata, C. Goddard, C. Pieler, E. Canalis, T.L. McCarthy \& M. Centrella: Recombinant transforming growth factor type beta3: Biological activities and receptor binding properties in isolated bone cells. Mol. Cell. Biol. 10, 4473-4479 (1990)

75. Graycar, J.L., D.A. Miller, B.A. Arrcik, R.M. Lyons, H.L. Moses \& R. Derynck: Human transforming growth factor beta3: recombinant expression, purification, and biological activities in comparison with transforming growth factors beta1 and beta2. Mol.

Endocrinol. 3, 1977-1986 (1989)

76. Takeuchi, Y., S. Fukumoto \& T. Matsumoto: Relationship between actions of transforming growth factor (TGF-)beta and cell surface expression of its receptors in clonal osteoblastic cells. J. Cell. Physiol. 162, 315-321 (1995)

77. Takeuchi, Y., K. Nakayama \& T. Matsumoto: Differentiation and cell surface expression of transforming growth factor-beta receptors are regulated by interaction with matrix collagen in murine osteoblastic cells. J. Biol. Chem. 271, 39383944 (1996)

78. Iseki, S., N. Osumi-Yamashita, K. Miyazano, P. Franzen, H. Ichijo, H. Ohtani, Y. Hatashi \& K. Eto: Localization of transforming growth factor-beta type I and type II receptors in mouse development. Exp. Cell. Res. 219, 339-347 (1995)

79. Iimura, T., S. Oida, H. Ichijo, M. Goseki, Y. Maruoka, K. Takeda, S. Sasaki: Modulation of responses to TGF-beta by 1,25 dihydroxyvitamin D3 in MG-63 osteoblastic cells: possible involvement of regulation of TGF-beta type II receptor. Biochem. Biophys. Res. Commun. 204, 918-923 (1994)

80. Nakayama, H., F. Ichikawa, J.L. Andres, J. Massague \& M. Noda: Dexamethasone enhancement of betaglycan (TGF-beta type III receptor) gene expression in osteoblast-like cells. Exp. Cell. Res. 211, 301-306 (1994)

81. Sankar, S., N. Mahooti-Brooks, T.L. McCarthy, M. Centrella \& J.A. Madri: Modulation of transforming growth factor beta receptor levels on microvascular endothelial cells during in vitro angiogenesis. J. Clin. Invest. 97, 1436-1446 (1996)

82. Yamaguchi, A., T. Katagiri, T. Ikeda, J.M. Wozney, V. Rosen, E.A. Wang, A.J. Kahn, T. Suda $\&$ S. Yoshiki: Recombinant human bone morphogenetic protein-2 stimulates osteoblastic maturation and inhibits myogenic differentiation in vitro. J. Cell Biol. 113, 681-687 (1991)

83. Hiraki, Y., H. Inoue, C. Shigeno, Y. Sanma, H. Bentz, D.M. Rosen, A. Asada \& F. Suzuki: Bone morphogenetic proteins (BMP-2 and BMP-3) promote growth and expression of the differentiated phenotype of rabbit chondrocytes and osteoblastic MC3T3-E1 cells in vitro. J. Bone Mineral Res. 6, 1373-1385 (1991)

84. Chen, T.L., R.L. Bates, A. Dudley, R.G. Hammonds \& E.P. Amento: Bone morphogenetic protein-2b stimulation of growth and osteogenic phenotypes in rat osteoblast-like cells: comparison with TGF-beta1. J. Bone Mineral Res.6:1387-1393 (1991)

85. Thies, R.S., M. Bauduy, B.A. Ashton, L. Kurtzberg, J.M. Wozney \& V. Rosen: Recombinant human bone morphogenetic protein-2 induces osteoblastic differentiation in W-20-17 stromal cells. Endocrinology 130, 1318-1324 (1992) 
86. Rosen, V., J. Nove, J.J. Song, R.S. Thies, K. Cox \& J.M. Wozney: Responsiveness of clonal limb bud cell lines to bone morphogenetic protein 2 reveals a sequential relationship between cartilage and bone cell phenotypes. J. Bone Mineral Res. 9, 1759-1768 (1994)

87. Centrella, M., T.L. McCarthy \& E. Canalis: Current Concepts Review: transforming growth factor-beta (TGF-beta) and remodeling of bone. $J$. Bone and Joint Res. 73-A, 1418-1428 (1991)

88. Carrington, J.L. \& A.H. Reddi: Temporal changes in the response of chick limb bud mesodermal cells to transforming growth factor betatype 1. Exp. Cell Res. 186, 368-373 (1990)

89. Carrington, J.L., P. Chen, M. Yanagishita \& A.H. Reddi: Osteogenin (bone morphogenetic protein-3) stimulates cartilage formation by chick limb bud cells in vitro. Dev. Biol. 146, 406-415 (1991)

90. Chen, P., J.L. Carrington, R.G. Hammonds \& A.H. Reddi: Stimulation of chondrogenesis in limb bud mesoderm cells by recombinant bone morphogenetic protein 2B (BMP-2B) and modulation by transforming growth factor beta1 and beta2. Exp. Cell Res. 195, 509-515 (1991)

91. Chen, P., J.L. Carrington, V.M. Paralkar, G.F. Pierce \& A.H. Reddi: Chick limb bud mesodermal cell chondrogenesis: inhibition by isoforms of platelet-derived growth factor and reversal by recombinant bone morphogenetic protein. Exp. Cell Res. 200, 110-117 (1992)

92. Niswander, L. \& G.R. Martin: FGF-4 and BMP-2 have opposite effects on limb growth. Nature (London) 361, 68-71 (1993)

93. Kingsley, D.M., A.E. Bland, J.M. Grubber, P.C. Merker, L.B. Russell, N.G. Copeland \& N.A. Jenkins: The mouse short ear skeletal morphogenesis locus is associated with defects in a bone morphogenetic member of the TGF beta superfamily. Cell 71, 399-410 (1992)

94. Centrella, M., V. Rosen, J.M. Wozney, S.R. Casinghino \& T.L. McCarthy: Opposing effects by glucocorticoid and bone morphogenetic protein-2 in fetal rat bone cell cultures. J. Cellular Biochem. 67, 528-540 (1997)

95. Bloom, B.B., D.E. Humphries, P.-P. Kuang, A. Fine \& R.H. Goldstein: Structure and expression of the promoter for the R4/ALK5 human type I transforming growth factorbeta receptor: regulation by TGF-beta. Biochim. Biophys. Acta 1312, 243-248 (1996)

96. Ji, C., S. Casinghino, T.L. McCarthy \& M. Centrella: Multiple and essential Sp1 binding sites in the promoter for transforming growth factor-beta type I receptor. J. Biol. Chem. 272, 21260-21267 (1997)

97. Saffer, J.D., S.P. Jackson \& M.B. Annarella: Developmental expression of Sp1 in the mouse. Mol. Cell. Biol. 11, 2189-2199 (1991)

98. Ji, C., S. Casinghino, D.J. Chang, Y. Chen, A. Javed, Y. Ito, S.W. Hiebert, J.B. Lian, G.S. Stein, T.L. McCarthy \& M. Centrella: CBFa(AML/PEBP2)related elements in the TGF-beta type $\mathrm{I}$ receptor promoter and expression with osteoblast differentiation. J Cell Bichem (In Press)

99. Ogawa, E., M. Maruyama, H. Kagoshima, M. Inuzuka, J. Lu, M. Satake, K. Shigesada \& Y. Ito: PEBP2/PEA2 represents a family of transcription factors homologous to the products of the Drosophila runt gene and the human $A M L 1$ gene. Proc. Natl. Acad. Sci. USA 90, 6859-6863 (1993)

100. Ogawa, E., M. Inuzuka, M. Maruyama, M. Satake, M. Naito-Fujimoto, Y. Ito \& K. Shigesada: Molecular cloning and characterization of PEBP2beta, the heterodimeric partner of a novel Drosophila runt-related DNA binding protein PEBP2 . Virology 194, 314-331 (1993)

101. Bae, S.-C., E. Ogawa, M. Maruyama, H. Oka, M. Satake, K. Shigesada, N.A. Jenkins, D.J. Gilbert, N.C. Copeland \& Y. Ito: PEBP2alphaB/mouse AML1 consists of multiple isoforms that possess differential transactivation potentials. Mol. Cell. Biol. 14, 3242-3252 (1994)

102. Levanon, D., V. Negreanu, Y. Berstein, I. BarAm, L. Avivi \& Y. Groner: AML1, AML2, and AML3, the human members of the runt domain genefamily: cDNA structure, expression, and chromosomal localization. Genomics 23, 425-432 (1994)

103. Tanaka, T., K. Mineo, K. Ueki, K. Tanaka, Y. Imai, K. Mitani, K. Okazaki, N. Sagata, Y. Yazaki, Y. Shibata, T. Kadowaki \& H. Hirai: The extracellular signal-regulated kinase pathway phosphorylates AML1, an acute myeloid leukemia gene product, and potentially regulates its transactivation ability. Mol. Cell. Biol. 16, 3967-3979 (1996)

104. Satake, M., T. Ibaraki, Y. Yamaguchi \& Y. Ito: Loss of responsiveness of an AP1-related factor, PEBP1, to 12$O$-tetradecanoylphorbol-13-acetate after transformation of NIH $3 \mathrm{~T} 3$ cells by the Ha-ras oncogene. J. Virology 63, 3669-3677 (1989)

105. Zhang, D.-R., C.J. Hetherington, S. Meyers, K.L. Rhoades, C.J. Larson, H.-M. Chen, S.W. Hiebert \& D.G. Tenen: CCAAT enhancer binding protein $(\mathrm{C} / \mathrm{EBP})$ and AML-1 (CBFalpha2) synergistically activate the macrophage 
colony-stimulating factor receptor promoter. Mol. Cell. Biol. 16, 1231-1240 (1996)

106. Oelgeschlager, M., I. Nuchprayoon, B. Luscher \& A.D. Friedman: C/EBP, c-Myb, and PU.1 cooperate to regulate the neutrophil elastase promoter. Mol. Cell. Biol. $16,4717-4725$ (1996)

107. Britos-Bray, M. \& A.D. Friedman: Core binding factor cannot synergistically activate the myeloperoxidase proximal enhancer in immature myeloid cells without c-Myb. Mol. Cell. Biol. 17, 5127-5135 (1997)

108. Umayahara, Y., C. Ji, M. Centrella, P. Rotwein \& T.L. McCarthy: CCAAT/enhancer binding protein delta (C/EBPdelta) activates insulin-like growth factor-I gene transcription in osteoblasts: identification of a novel cyclic AMP signaling pathway in bone. J. Biol. Chem. 272, 3179331800 (1997)

109. Miyoshi, H., M. Ohira, K. Shimizu, K. Mitani, H. Hirai, T. Imai, K. Yokoyama, E. Soeda \& M. Ohki: Alternative splicing and genomic structure of the AML1 gene involved in acute myeloid leukemia. Nuc. Acids Res. 23, 2762-2769 (1995)

110. Meyers, S., N. Lenny \& S.W. Hiebert: The $t(8 ; 21)$ fusion protein interferes with AML-1B-dependent transcriptional activation. Mol. Cell. Biol. 15, 1974-1982 (1995)

111. Zhang, Y.-W., S.-C. Bae, G. Huang, Y.-X. Fu, J. Lu, M.-Y. Ahn, Y. Kanno \& Y. Ito: A novel transcript encoding an n-terminally truncated AML1/PEBP2alphaB protein interferes with transactivation and blocks granulocytic differentiation of 32Dc13 myeloid cells. Mol. Cell. Biol. 17, 4133-4145 (1997)

112. Zhu, X., J.E. Yeadon \& S.J. Burden: AML1 is expressed in skeletal muscle and is regulated by innervation. Mol. Cell. Biol. 14, 8051-8057 (1994)

113. Merriman, H.L., A.J. van Wijnene, S. Hiebert, J.P. Bidwell, E. Fey, J. Lian, J. Stein \& G.S. Stein: The tissuespecific nuclear matrix protein, NMP-2, is a member of the $\mathrm{AML} / \mathrm{CBF} /$ runt domain transcription factor family: interactions with the osteocalcin gene promoter. Biochemistry 34, 13125-13132 (1995)

114. Ducy, P. \& G. Karsenty: Two distinct osteoblastspecific cis-acting elements control expression of a mouse osteocalcin gene. Mol. Cell. Biol. 15, 1858-1869 (1995)

115. Geoffrey, V., P. Ducy \& G. Karsenty: A PEBP2 alpha/AML1-related factor increases osteocalcin promoter activity through its binding to an osteoblast-specific cisacting element. J. Biol. Chem. 270, 30973-30979 (1995)

116. Banerjee, C., S.W. Hiebert, J.L. Stein, J.B. Lian \& G.S. Stein: An AML-1 consensus sequence binds an osteoblast-specific complex and transcriptionally activates the osteocalcin gene. Proc. Natl. Acad. Sci. USA 93, 49684973 (1996)

117. Banerjee, C., L.R. McCabe, J.-Y. Choi, S.W. Hiebert, J.L. Stein, G.S. Stein \& J.B. Lian: Runt homology domain proteins in osteoblast differentiation: AML3/CBFA1 is a major component of a bone-specific complex. J. Cellular Biochem. 66, 1-8 (1997)

118. Ducy, P., R. Zhang, V. Geoffrey, A.L. Ridall \& G. Karsenty: Osf2/Cbfa1: a transcriptional activator of osteoblast differentiation. Cell 89, 747-754 (1997)

119. Komori, T., H. Yagi, S. Nomura, A. Yamaguchi, K. Sasaki, K. Deguchi, Y. Shimizu, R.T. Bronson, Y.-H. Gao, M. Inada, M. Sato, R. Okamoto, Y. Kitamura, S. Yoshiki \& T. Kishimoto: Targeted disruption of Cbfal results in a complete lack of bone formation owing to maturational arrest of osteoblasts. Cell 89, 755-764 (1997)

120. Otto, F., A.P. Thornell, T. Crompton, A. Denzel, K.C. Gilmour, I.R. Rosewell, G. W. H. Stamp, R. S. P. Beddington, S. Mundlos, B.R. Olsen, P.B. Selby \& M.J. Owen: $C b f a 1$, a candidate gene for cleidocranial dysplasia syndrome, is essential for osteoblast differentiation and bone development. Cell 89, 765-771 (1997)

121. Mundlos, S., F. Otto, C. Mundlos, J.B. Mulliken, A.S. Aylsworth, S. Albright, D. Lindhout, W. G. Cole, W. Henn, J. H. M. Knoll, M.J. Owen, R. Mertelsmann, B.U. Zabel \& B.R. Olsen: Mutations involving the transcription factor CBFA1 cause cleidocranial dysplasia. Cell 89, 773-779 (1997)

122. Chang, D.J., C. Ji, K.K. Kim, S. Casinghino, T.L. McCarthy \& M. Centrella: Reduction in CBFa1 and TGFbeta receptor I on bone cells by glucocorticoid. J. Biol. Chem. 273, (1998, in press)

Key words: Biochemistry and molecular biology, bone, osteoblasts, TGF-beta receptors, Cloning, sequencing, gel shift, RNA and protein analyses

Send correspondence to: Michael Centrella, Department of Surgery, Plastic Surgery Section, Yale University School of Medicine, 333 Cedar Street, PO Box 208041, New Haven, CT 06520-8041, Tel: (203) 785-4927, Fax: (203) 785-5714, E-mail: michael.centrella@yale.edu 